GLOBAL JOURNAL OF EDUCATIONAL RESEARCH VOL 19, 2020: 1-7

COPYRIGHT@ BACHUDO SCIENCE CO. LTD PRINTED IN NIGERIA. ISSN 1596-6224

www.globaljournalseries.com; Info@globaljournalseries.com

\title{
AN ASSESSMENT OF SEX, SCHOOL TYPE AND RETENTION ABILITY IN BASIC TECHNOLOGY ACHIEVEMENT AMONG SENIOR SECONDARY SCHOOL STUDENTS
}

HENRIETTA O. UCHEGBUE AND MELVINA N. AMALU

(Received 19, November 2019; Revision Accepted 3, February 2020)

\begin{abstract}
Given the laudable purposes attached to study of Basic Technology in JSS, it is therefore important that students retain the skills and knowledge acquired in the course of studying the subject in the school. However, sadly, the intended effect Basic Technology as a subject in the secondary school system should have, has not been seen in the generation of able manpower readily employable for the economy. The study investigated the difference between the retention ability of male and female senior secondary students in Basic Technology, and how school type (public/private) influence retention. Two research hypotheses were formulated for the purpose of the study. The research design used in carrying out this study is Ex-post facto design. This study covered the Southern Educational Zone of Cross River State, Nigeria. The population of the study comprised all senior secondary school three (SS3) students in the government-owned secondary schools and private-owned secondary schools in the southern educational zone of Cross River State. The sampling technique used is stratified random sampling technique. The sample size for this study was 487 senior secondary school three (SS3) students drawn from fourteen schools in seven local government areas of southern educational zone. The research instrument used in the study is the achievement test. The statistical analyses techniques adopted to analyze the data collected were dependent t-test and independent t-test respectively. Findings of the study showed that there is no significant difference in retention between males and females, public and private schools in senior secondary school in Basic Technology. Based on the findings of the study, recommendations were made which include that there is a need to focus on the female folks in the execution of national policy on education. This study shows that the female folk are capable of achieving and retaining as much the male folks during learning. Much effort should be made by the government to bridge the disparity between male and female folks in enrolment into and completion of the secondary school education.
\end{abstract}

KEYWORDS: gender, retention ability, achievement, technology, school type.

\section{INTRODUCTION}

The publication of the new National Policy on Education in 1981 was regarded as one of the boldest steps towards the eradication of many of the country's educational and social ills. The secondary school curriculum today perceives education as an integral part of life instead of mere preparation for adult life. Emphasis is laid on establishing a form of thought and understanding inherent in the classical view of curriculum and relating it to experience

Henrietta O. Uchegbue, Department of Educational Foundations, University of Calabar, Calabar, Nigeria.

Melvina N. Amalu, Department of Educational Foundations, University of Calabar, Calabar, Nigeria. 
awareness, creativity and unity of knowledge. The production of skilled manpower is becoming the ultimate end of education in Nigeria and as such, the student must be given knowledge, skills and abilities to enable him engage in profitable employment on completion of any state of education.

Among the variety of subjects for the first three years of secondary education called the Junior Secondary School (JSS), the national policy on education places Basic Technology among the core subjects. The pre-vocational nature of the junior secondary school makes the study of Basic Technology mandatory to all the students. Being an integrated rudimentary study of basic western technology, and coupled with the fact that its study is compulsory for the first three years in the secondary school, the issue of retention and achievement in Basic Technology becomes a concern to education system of Nigeria.

The National Policy on Education declared the general aim of primary, secondary and tertiary education levels as to pursue effective science and technology programmes which would enable the citizenry adapt to the rapid techno-scientific development of the nation (Federal Ministry of Education (FME), 2004). According to the National Policy on Education (2004), Basic Technology is one of the core subjects on which the Federal Government places high premium. It is to be taken at JSS level (Federal Ministry of Education, 2004). Technology education should result in the acquisition of practical skills, attitudes, understanding and knowledge relating to occupations in the various aspects of our economic and social life. Technology as grouped under Technical and Vocational Education is further understood to be:

- $\quad$ An integral part of general education

- A means of preparing for occupational fields and for effective participation in the world of work

- $\quad$ An aspect of life-long learning and a preparation of responsible citizenship

- An instrument for promoting environmentally sound sustainable development

- A method of alleviating poverty

The preparatory aspect of pre-vocational training offered to students at the junior secondary level is for the purpose of:

1. Introduction into the world of technology and appreciation of technology toward interest arousal and choice of a vocation at the end of junior secondary school, and professionalism later in life.
2. Acquiring technical skills

3. Exposing students to career awareness by exploring usable options in the world of work.

4. Enabling youths to have an intelligent understanding of the increasing complexity of technology

Retention could be said to be ability of a student to store, retain and subsequently recall information learnt in the classroom or in the course of study. Farrant, (2002) believed that increase in knowledge lies solely on the ability to remember. He further explained that if an individual could not grasp and keep hold of what was taught and learnt, it would seem like trying to fill a bucket without bottom with water. This means that if one cannot retain what one learnt then there's no need expecting one to perform in that activity in the future. The current state of achievement and retention in the secondary school system in science-related subjects such as Basic Technology has been characterized by some scholars as poor (Anderson, 2001; Ogunleye, 2002; Freedman, 2002; Omoniyi, 2006; Azubuike 2005; Nwagbo 2001). The West African Examination Council report on candidates' performance in Senior Secondary School Certificate Examination (2008) equally expressed concern at the deteriorating trend in performance of candidates over the years in science-related subjects. If this trend of low achievement is allowed to continue unabated, it will be difficult to achieve the goals of science education programme in the National Policy on Education.

The discovery and inquiry approaches of science and technology teaching are the recommended approaches adopted by many nations to revolutionize science and technology teaching and learning (Oghenevwede, 2010). Emphasis has shifted from traditional teaching strategies which revolves hand-on minds-on science activities (Azubuike 2005). Discovery (Heuristic) approach in recent years gained prominence as a fascinating teaching strategy in science technology education. This is because educators became disenchanted with the concept of the teacher as the transmitter of knowledge. Discovery is a method which offers learners the opportunity to discover scientific facts, concepts and principles for themselves rather than being told. It gives learners the opportunity to discover and learn science and technology from their own participation. Inquiry approach on the other hand is a teaching strategy which attempts to help learners ask questions and discover answers to their questions. Inquiry method permit and 
observe an event, recognize relevant and irrelevant questions, search out data and take complete responsibility for an entire process of obtaining, organizing and interpreting data (Oghenevwede, 2010). If adopted in Basic Technology teaching and learning in the secondary school sub-sector, these strategies could help students learn and understand better. This would in turn enhance retention of knowledge gained and lessons learnt on the long term.

A study carried out by Eldis (2006) in Botswana and Ghana about sex differentiation in students' educational retention and levels of achievement, reveal a highly sexed school environment, which served to constrain the learning opportunities, particularly of girls, and to encourage sex segregation and stereotypical sex behavior. Institutional practices were rarely questioned by either staff or students. Other findings made by him further reveal that;

The sexed school environment influences achievement in particular with girls achieving at a lower level than boys. Whereas males outperformed females in all school categories in Ghana, in Botswana two of the three low performing schools had sex gaps in favour of girls.

Good school management can counter-balance the relationship between sex and low performance to certain extent. However, the link between high achievement and good school management existed regardless of whether the Head teacher was male or female.

As regards school type, organizational theory suggests that competition from private schools (which is enhanced by retention) affects the organizational structure of public schools. Hence, by changing the organizational structure of public schools, competition which is aided by achievement from private schools enhances student performance in public schools (Arum 1996) as quoted in Obukohwo (2004).

Research findings indicate that increase in the number of private schools has significant impact on the performance of public schools. Retention and achievement test in basic technology and science shows higher average scores for private school students as reported by Arum (1996). Moreso, private schools tend to require more years of core academic subjects for high school graduation than the public schools.

According to Gobir (2005), public schools usually have highly qualified, experienced teachers, which help to enhance achievement and result to good retentive ability. However, this comparative advantage may be mitigated by poor supervision and unsatisfactory treatment of teachers by government. Many private owners, especially at the secondary school levels, cannot afford to have quality schools with good and efficient staff and up-to-date laboratories and workshops. Some very few private schools are trying to provide state-of-the-art facilities and investing in technological innovation, which can invariably enhance retention.

Furthermore, Gobir says that private schools tend to maintain more conducive environment for learning. There is better discipline, and increased level of dedication on the part of parents who send their children to private schools. Such parents wants their children to take advantage of the best the schools offer. All these factors listed above enhance retention.

In a study carried out by Nwokocha and Amadike (2005) to compare academic performance in private and public secondary schools in River State, using WASSCE of 20012004 , it was discovered that there is higher percentage in academic performance which is as a result of the retentive ability of the students in favour of private schools. This implies that there is a significant difference between academic performance of students in private and public schools' WASSCE.

Given the above laudable purposes attached to study of Basic Technology in JSS, it is therefore important that students retain the skills and knowledge acquired in the course of studying the subject in the school. Every child must be encouraged to use his/her brain and hands in learning. Hence a child that has been exposed to such learning experience like Basic Technology will definitely expose him/herself to be filled with the burning desire for achievement and selfimprovement.

\section{Statement of the problem}

Given the applaudable vision and purpose attached to the study of Basic Technology as a subject in secondary school, the intended effect has not been seen in the generation of able manpower readily employable for the economy. In other words, the purposes behind the study of Basic Technology as a subject is not being achieved or attained. There is a consensus among observers of the education sector and the economy on an apparent failure of the Basic Technology Programme in schools. Most of the students complained that they did not gain the experience they hoped for from the subject. Majority claimed that they never visited the workshop or touched any tool throughout their 
three years study of Basic Technology. Some confessed that their interest in technical subjects was killed by their inability to gain any new experience from their study of Basic Technology. They generally felt that their study of Basic Technology had not influenced their lives positively. However, considerable amount of money had been invested in every state for ensuring that the appropriate learning experiences were made available to students. Given this situation, it may be understandable the reason why the study of Basic Technology has not translated to real results for manpower and the economy as a whole. This is an urgent problem that must be solved, which has contributed to the reason for considering such a study as this, so as to contribute knowledge to finding solution to this problem.

\section{Purpose of the study}

The main purpose of this study is to examine retention in Basic Technology achievement among senior secondary school students in Cross River State, Nigeria. However, specifically, the study will investigate the difference between the retention ability of male and female senior secondary students in Basic Technology, and the impact of school type on retention in Basic Technology.

\section{Research question}

- To what extent is there a difference between the retentive ability of male and female senior secondary students in Basic Technology?

- $\quad$ Does school type (public, private) impact students' retention in Basic Technology.

\section{Research hypothesis}

The following hypothesis tested in this study is hereby stated in null form:

- There is no significant difference in retention between males and females in senior secondary school in Basic Technology.

- There is no significant difference between secondary school students' achievement in Basic Technology in JSS3 and their achievement in SS3 among public and private schools.

\section{Research methodology}

The research design used in carrying out this study is Ex-post facto design. This was chosen because of its ability to study population by selecting sample chosen from the population to discover the interrelations of variables. It can also be used to measure relationships among sociological and psychological variables.

This study area is the Southern Educational Zone of Cross River State, Nigeria. Southern educational zone comprises seven local government areas with a total number of seventytwo public secondary schools and twelve private schools. Cross River State is located in the rain forest zone of West Africa. It is found between longitude $7^{0}$ to $9^{0}$ East and $4^{0}$ North. It is bounded on the North by Benue State, on the south by the Atlantic Ocean, on the East by the Cameroun, and the West by Abia, Ebonyi and Akwa-lbom States. The people of Cross River State are predominantly Christians. Most of the secondary schools in southern education zone are mixed schools comprising of boys and girls, only very few are boy or girl schools.

The population of the study comprised all senior secondary school three (SS3) from seventy-two (72) government-owned secondary schools and twelve (12) private-owned secondary schools in the southern educational zone of Cross River State. These students in the government-owned schools numbered 38,240 and 219 in privateowned schools in the 2005/2006 year. The choice of the senior secondary school was based on the fact that they have studied Basic Technology for three years during the junior secondary school setting and so should be able to answer questions they attempted in their junior secondary examinations bearing in mind that it is expected of every student that offered Basic Technology to use the acquired knowledge for future self and societal development.

The sample size for this study is 487 senior secondary school three (SS3) students drawn from fourteen schools in seven local government areas of southern educational zone. The stratified random sampling technique was adopted as sampling procedure in this study. Stratified random sampling, according to Isangedighi, Joshua, Asim and Ekuri (2004) is used when the population contains definite subsets, each of which is distinctly different, though within each stratum the units are homogeneous. The schools in the educational zone were first of all stratified according to local government areas, followed by school location (urban and rural) and then school type (public and private). The total number of schools selected therefore was 14 .

The research instrument used in the study is the achievement test. The instrument was already constructed by the Basic Technology teachers in the various schools. The teachers are professionals and it is assumed that all the questions have been set according to standard. The researcher being a Basic Technology teacher, have ensured that the questions cover JSS1 to JSS3 syllabus. 
Data collection procedure

The researcher visited fourteen schools and personally administered the test on the concerned respondents with the help of the principals, vice principals and subject teachers in the selected schools of study. The students were made to understand the objective of the study. The tests were administered and the scripts collected back that same day. At the end of data collection, 487 scripts were retrieved back from the respondents.

\section{Procedure for data analysis}

The statistical analysis techniques used to analyze the data collected were dependent t-test and independent t-test respectively.

\section{RESULTS}

Test of hypotheses

$\mathrm{H}_{0}$ : There is no significant difference in retention between males and females in senior secondary school in Basic Technology

Variables: Male retention and Female retention $\mathrm{H}_{0}$ : There is no significant difference between secondary school students' achievement in Basic Technology at JSS3 and their achievement in SS3 among public and private schools.

Variables: public and private schools retention Statistical tool: independent t-test

Dependent t-test analysis of the difference between Basic Technology achievement in JSS3 and SSS3 in each of the sex groups. The hypothesis was tested and the result of the effect of the independent variables (male, female) is presented in Table 1

Table 1: Summary of the dependent t-test analysis of difference between Basic Technology achievement at JSS3 and SSS3 in each of the sex groups.

\begin{tabular}{|c|l|l|l|l|}
\hline Group Variables & N & Mean & SD & T \\
\hline Males Basic Tech. ach. In JSS3 & 249 & 49.43 & 10.25 & \\
\hline Basic Tech. ach. In SSS3 & 249 & 50.02 & 10.32 & -0.804 \\
\hline Females Basic Tech. ach. In JSS3 & 238 & 50.60 & 9.45 & \\
\hline Basic Tech. ach. In SSS3 & 238 & 49.98 & 9.36 & 0.763 \\
\hline
\end{tabular}

$\mathrm{T}$-value is not significant at 0.05 level critical $\mathrm{t}=1.96 \mathrm{df}$ for males, 248 , female 237

The null hypothesis states that there is no significant difference in retention ability between males and females in senior secondary school in Basic Technology achievement. From the statistical analysis, the result shows that there is no significant difference between Basic Technology achievement at JSS3 and SSS3 in each of the sex groups. This is because the calculated t-value for males, -0.804 is less than the critical t-value 1.96, and the calculated t-value for females, 0.763 is less than the critical t-value. Therefore, we do not have sufficient evidence to reject the null hypothesis, the null hypotheses is hereby retained and we conclude that there is no significant difference in retention ability between males and females in senior secondary school in Basic Technology achievement.

Table 2: Summary of the independent t-test analysis of effect of type of school on students' retentive ability in Basic Technology

\begin{tabular}{|l|l|l|l|l|l|l|}
\hline School type & Variables & N & Mean & SD & T & Df \\
\hline Public & Basic Tech. Ach. in JSS3 & 316 & 49.96 & 9.97 & & \\
\hline & Basic. Tech. Ach. in SS3 & 316 & 50.27 & 9.87 & .453 & 315 \\
\hline Private Basic. & Tech. Ach. in JSS & 171 & 50.07 & 9.73 & & \\
\hline & Basic. Tech. Ach. in SS3 & 171 & 49.49 & 9.91 & 645 & 170 \\
\hline
\end{tabular}

$\mathrm{t}$-value is not significant at. .05 level, critical $\mathrm{t}=1.96$.

The null hypothesis says that there is no significant difference between Basic Technology achievement at JSS3 and SS3 in each of the school type (public and private).

From the statistical analysis, the result shows that there is no significant influence of school type on Basic Technology achievement in JSS3 and SS3 in each of the school groups. This is because the calculated t-value for public schools is .453, which is less than the critical t-value 1.96. And also the calculated t-value for private schools .645, which is less than the critical tvalue 1.96. Therefore, the null hypothesis is hereby retained. 


\section{DISCUSSION}

The findings of this study supported by lloputaife (2001) and Eze (2001) in their independent studies on achievement and retention of physics students found that male and female students who offer physics have no significant difference in their mean achievement and retention in physics. Furthermore, the findings of this study are corroborated by Eze (1992) in his study, he found that the difference between the students' (male and female) mean post treatment retention test in physics was not significant.

However, the findings of this study seem to be in disagreement with the findings of Onekutu and Onekutu (2002) who in their studies found out that male students achieve and even retain what they have learnt better than their female counterparts at the secondary school level. The reason for this difference could be that female students have phobia for the teaching and learning of Basic Technology as a subject in the secondary school.

The result also showed that there is no significant difference between public and private schools as regards school type. The finding of this study is not in consonance with the finding of Gobir (2005), who stated that private schools tend to maintain more conducive environment for learning, better discipline, increased level of education, all these factors enhance retention. Nwokocha and Amadike (2005) in agreement stated in their study that there is higher percentage in academic performance which is as a result of high retentive ability of the students in favour of private schools.

\section{CONCLUSION}

The findings of this study indicated that the sex variable when taken per group (males, females) do not significantly influence retention in Basic Technology among SSS3 students. In other words, the sex variable does not predict retention ability in Basic Technology among senior secondary students.

The type of school variable when considered pergroup (Public, private) do not significantly influence retention ability in Basic Technology among JSS3 and SS3 students.

There is a close difference between JSS3 and SS3 students achievement as the number of the students who retained knowledge were 321 out of 487 involved in the study, while those who did not retain knowledge were 166 . Which shows that majority of the students retained knowledge gained in Basic Technology which may be due to continual exposure in other closely related subjects of study.

The sex and school type (SCHTYPE) variables do not predict retention ability among senior secondary school students.

Invariably, Sex difference do not influence retention ability among senior secondary school students in Basic Technology. Whether the school is public or private do not influence retention in Basic Technology.

\section{RECOMMENDATIONS}

Based on the findings of this study, the researcher believes that the following recommendations will help enhance the extent of retention ability in Basic Technology among senior secondary school students:

1. Much effort should be made by the government to bridge the disparity between male and female folks in enrolment into and completion of the secondary school education because the female folks are capable of achieving and retaining as much as their male counterparts during learning.

2. The private school proprietors and governmental bodies should provide study materials (audio-visual), equip their schools' workshops and also make the classrooms conducive in order to improve learning, memory and retention in Basic Technology.

3. Parents, Teachers Association (PTA) can be sensitized on how to expose their wards by allowing them to practice with some electrical fittings, minor repairs, some carpentry jobs, etc at home. This will help to concretize the knowledge in Basic Technology thereby enhancing the retentive ability of students.

4. The national policy makers should make it mandatory that only qualified teachers be allowed to teach particularly a core subject like Basic Technology, since this will help to promote true knowledge.

5. The school counsellors should sensitize the students on the importance of good study habits for proper retention by organizing seminars at the beginning of each session.

\section{REFERENCES}

Anderson, A., 2001: Learning Strategies. The Missing Thing in Physical Education and Coaching. A Practical Guide to the Development of Strategies Learners. Toronto: Sport Books Publishers. 
Azubuike, A. S., 2005. Inquiry and problem solving approach. Integrated science education series: No 3. Approach to the teaching of you and your home of STAN. pp 20-26

Eze, A. N., 1991. Sex and Environment as Factors in Physics Achievement. International Journal of Education Research $17-23$.

Ezeh, O. E., 2001. Effect of Practical Skills in Academic Achievements. Unpublished Manuscript. UNN.

Farrant, J. S., 2002: Principles and Practice of Education. London. Longman Group U. K Ltd.

Federal Ministry of Education F.M.E., 2004. National Curriculum for Senior Secondary Schools. Lagos: Federal Ministry of Education.

Federal Republic of Nigeria, (Revised 2004) National Policy on Education, Abuja.

Freedman, M. P., 2002: The Influence of Laboratory Instruction on Science Achievement and Attitude Towards Science Across Gender Differences. Journal of Women Minority in Science and English. 8(2) 50.

Gobir, B. G., 2005. Nigeria Journal of Educational Administration and planning. Public-Private school Debate lessons to be learned by Nigeria PP.118. Vol. 5 (2). July 2005.

Iloputaife, E. C. (2001). Effects of Analogy and Conceptual Change Instructional Models on Physics Acheivement of Secondary School Students. Unpublished Ph.D Thesis. UNN.

Iloputaife, E. C., Obi, M. A. C., Emere, F. N., Nwosa, J. C. and Ugwuanyi J. U., 1984. The Guided Discovery and Expository Methods of Task Presentation among class three Secondary

School
Physics Students.

Unpublished B.Sc Project UNN.

Isangedighi, A. J., Joshua, M. T., Asim A. E. and Ekuri, E. E., 2004. Fundamentals of research and statistics in education and social sciences. Calabar: University of Calabar Press.

Jegede, O. J. Otuka, O. E. and Eniayeju, P. A., 1992. Raising the Standard of Performance in Public Examinations in Science, Technology and Mathematics Journal of Science Teachers' Association of Nigeria, 28 (1) 123 - 124.

McClelland, D. C., 1961. The achieving society. New York: Van Nastrand.

Nwagbo, C. R., 1999. Effects of Guided Discovery and Expository Teaching Methods on Attitude Towards Biology Students of Different Levels of Scientific Literacy. Journal of Science Teachers Association of Nigeria. 35 (12), 66 - 73.

Oghenevwede, O. E., 2010. Effects of discovery and inquiry Approaches in teaching and learning of Biology on secondary schools students' Performance in delta state, Nigeria. Journal of Research in Education and Society, Vol.1 No.1.

Ogunleye, A. D., 2002. Prospects and Problems in Physics Education in Nigeria Secondary Schools. African Journal of Education: 1(1). 154 - 167.

Omoniyi, O. A., 2006. The Effect of Constructivist Based Teaching Strategy on GenderRelated Differences on Students' Misconceptions in Chemistry. Ministry of Education, Akure, Nigeria.

Onekutu, A. and Onekutu, P. O., 2002. Gender Differences in Achievements in JSS Examinations in Integrated Science: Implication for National Development. In O. O. Okpheh (ed) Review of Gender Studies in Nigeria. 